Studia i Materiały, 2/2016 (22), cz. 2: 201-212

\title{
Foreign Direct Investment and Investment Development Path. The Case of Visegrad Countries
}

\author{
Grzegorz Tchorek*
}

The main aim of the article is to describe shortly the role of FDI in economic transformation and increasing export capabilities of the Visegrad countries. In the first part potential benefits of FDI are described, and in the second one conditionality of gaining profits from FDI presence is outlined. The third part is dedicated to analysing the relation between the FDI inflow and the ability to export FDI using the concept of Investment Development Path. In the fourth part, data and facts related to inward and outward FDI of the Visegrad countries are recalled. The main message from the article is that attracting FDI cannot be the goal in itself. It should serve to improve export and innovation capabilities of a local economy. It also demands a smart policy dedicated to attracting "good quality" investment. Potential benefits brought about by the FDI presence and access to related knowledge and technology depend on absorption capacity. Increased absorption capability of an economy, namely improved quality of production factors, enhances opportunities for capital export and presence in foreign markets in the form of FDI.

Keywords: export, foreign direct investment, spillover effects.

Submitted: 11.11.2016 | Accepted: 28.12.2016

\section{Bezpośrednie Inwestycje Zagraniczne a Inwestycyjna Ścieżka Rozwoju. Przypadek krajów grupy Wyszehradzkiej}

Gtównym celem artykutu jest przedstawienie roli BIZ $w$ transformacji gospodarczej $i$ podniesieniu zdolności eksportowych gospodarek państw grupy Wyszehradzkiej. W pierwszej części opisano możliwe korzyści z BIZ, natomiast $w$ drugiej warunki osiagania profitów $z$ obecności inwestorów zagranicznych. Trzecia część poświęcona jest analizie relacji między naptywem BIZ i zdolnościa do ich eksportu z wykorzystaniem koncepcji Inwestycyjnej Ścieżki Rozwoju. $W$ czwartej części przedstawiono dane oraz fakty zwiazane $z$ naptywem $i$ odplywem BIZ krajów grupy Wyszehradzkiej.

Gtównym przestaniem artykułu jest to, że przyciaganie inwestycji zagranicznych nie może być celem samym $w$ sobie. Powinny one stużý poprawie zdolności eksportowej i innowacyjnej gospodarki lokalnej. Wymaga to inteligentnej polityki przyciagania inwestycji „dobrej jakości”. Możliwość osiagania korzyści z obecności BIZ, ich wiedzy, technologii i dostępu do rynków zależa od cech określanych jako zdolności absorpcyjne. Zwiększanie możliwości absorpcyjnych gospodarki, oznaczające podniesienie jakości czynników wytwórczych, sprzyja

Grzegorz Tchorek - PhD, Faculty of Management, University of Warsaw.

Mailing address: Faculty of Management, University of Warsaw, 1/3 Szturmowa St., 02-678 Warsaw, Tchorek@wz.uw.edu.pl. Ministry of Science
and Higher Education Republic of Poland
The creation of the English-language version of these publications is financed in the framework of contract No. 768/P-DUN/2016 by the Ministry of Science and Higher Education committed to activities aimed at the promotion of education. 
możliwości eksportu kapitału i zwiększaniu obecności krajowych podmiotów na rynkach zagranicznych $w$ formie BIZ.

Słowa kluczowe: eksport, bezpośrednie inwestycje zagraniczne, efekty spillover.

Nadesłany: 11.11.2016 | Zaakceptowany do druku: 28.12.2016

JEL: F18, F21, F23

\section{The Role of FDI in Economic Transformation and Convergence}

FDI can be an important factor of economic growth and convergence between emerging and advanced economies. FDI inflows constitute a vital feature of the global economy and a significant aspect of international integration of production factors, especially for emerging markets. This also relates to Central Eastern European Countries (CEECs) employed into the "convergence machine", mainly thanks to the transformation and EU integration processes. Both literature and economic practice prove that in spite of some drawbacks related to the FDI capital (brain drain, stealing market as well as the conditions which have to be fulfilled in order to profit from the FDI presence), the balance of costs and benefits of such inflows is rather positive (Bruno and Campos, 2013). A common consensus indicates the following direct and indirect effects of FDI.

Firstly, FDI can constitute an important tool for macroeconomic restructuring, a driver for increasing productivity and competitiveness as well as an instrument for speeding up income levels growth. It is justified by the neoclassical as well as endogenous growth theories. In the first case, investment is an important driver of growth, providing higher capital stock per worker which is needed for economic development. In the second case, FDI should ensure knowledge and technology transfer, which is emphasized by new growth theories (Gammeltoft and Kokko, 2013). Among others, Damijan et al. (2013), Bijsterbosch and Kolasa (2010) find empirical evidence for the FDI influence on improving the export structure and productivity upgrade in CEECs.

Secondly, FDI is combined with trade flows, which constitutes an important factor of economic integration, especially in
CEECs. Growing trade between the EU and CEECs as well its structural improvement measured by technological content were a result of a massive FDI inflow mainly from richer EU countries (for literature review see Tchorek and Czaja, 2015). Companies with foreign investors in all CEECs are an important part of the so-called Global Value Chains and a source of supply of intermediate goods used in the production of final goods (Iossifov, 2014). Trade relations, including those enforced by Global Value Chains, can also be an important source of spillover effects (Hagemejer, 2015).

Thirdly, FDI inflows are more stable than portfolio inflows, which can be important for the exchange rate and financial stability, especially during crisis episodes. In terms of both financial stability and economic growth, FDI reveals the most desirable properties and is termed cold money contrary to portfolio flows, which are called hot money (Bluedorn et al., 2013). FDI is less susceptible to flows volatility and the contagion effect, i.a. because tangible assets are more "attached" to the investment country. Moreover, FDI is less susceptible to external "push" factors related to international risk (Broto et al., 2011; Brzozowski et al., 2014).

\section{Conditional Effects of FDI Profits for the Recipient Economy}

Benefits from the FDI presence are not automatic and depend on the FDI inflow structure. Apart from the scale of FDI inflows, their structure should also be taken into account. Empirical studies suggest that the composition of FDI inflows in the EU countries could determine labour productivity, economic competitiveness, and the magnitude of external imbalances (Mitra, 2011; Kinoshita, 2011). Countries with a higher share of more volatile and less productive FDI (especially in services - 
financial and renting sectors) can be more susceptible to shocks, which leads to a more volatile GDP growth. A higher share of manufacturing should impose more R\&D activity, trade competitiveness and access to knowledge. Investment in tradable goods is usually made in branches that have to deal with international competition, which can lead to increased productivity and operational elasticity. To a greater extent, effects of FDI on local economy depend on motives behind capital flows. The most widely used classification of FDI motives (proposed by Dunning, 1993) differentiates the following drivers of FDI.

Firstly, resource-seeking FDI. The main motivation for this type of FDI is to have access to specific resources (natural resources, raw materials, cheap labour force) in the host economy. This type of FDI is usually characterized by vertical links where subsidiaries are suppliers to the parent company.

Secondly, market-seeking FDI. The main motivation for this type of FDI is to direct supply of goods and services to the host countries. This type of FDI is characterized by horizontal links and subsidiaries usually produce the same goods as the parent company. Foreign investors exploit the opportunity offered by market size, GDP per capita and market growth.

Thirdly, efficiency-seeking FDI. This type of FDI usually occurs in order to "take advantage of different factor endowments, cultures, institutional arrangements, economic systems and policies, and market structures by concentrating production in a limited number of locations to supply multiple markets" (Dunning, 1993, p. 59). Similar to resource-seeking FDI, efficiencyseeking FDI is usually of vertical nature.

Fourthly, strategic asset-seeking FDI. The main motivation of such FDI is to acquire unique assets, knowledge, technology and build network relations in order to increase competitive advantage. The relation between a subsidiary and the parent company can be vertical or horizontal.

Benefits are usually lower for countries which are the target of resource-and market-seeking investment as Görg et al. (2009) showed based on Hungarian firmlevel data. Moreover, the main advantages of the FDI presence, namely spillover effects, are limited by many conditions and depend on the economy's absorptive capacity. From the theoretical point of view, the main source of profits from the FDI presence should be an access of local companies to international markets, new trends and technologies as well as management techniques. They are connected to transfer of knowledge and its diffusion to the local economy (Hanousek et al., 2009). Evidence based on empirical research indicates that real effects of the FDI presence are dependent on the ability to acquire and use knowledge thanks to the interaction with foreign firms. Moreover, the lack of spillovers or even negative effects may also occur (Gersl et al., 2007).

The following factors are usually defined as critical factors of absorptive capacity.

Human capital gap can be a very important factor of the knowledge accumulation absorption ability. Borensztein et al. (1999) suggest that in order to benefit from the FDI presence, countries must have a basic level of human capital able to accumulate and use intangible assets. High-skilled workers, including foreigners with network relations, can be an important mechanism of knowledge and skills transfer from abroad ${ }^{1}$. Moreover, a higher level of human capital should lead to more productive FDI than domestic investment only when the host country has a minimum threshold stock of human capital (Alfaro, 2015).

Institutional factors may play an important role in attracting FDI and spur transfer of knowledge to the local economy. Jude and Levieuge (2015) confirmed earlier hypotheses that institutional environment may affect the quantity and quality of FDI inflow and influence capital accumulation. The benefits from the FDI presence may be determined by institutional factors which influence the quality of interaction between foreign and local agents as well provide favourable conditions for local companies. Literature mentions the following factors: rule of law, political stability, low level of corruption, respect for ownership rights and economic freedom (Ali et al., 2010). Inefficient institutions which curb competition, freedom of choice and increase barriers to economic activity may cause higher transaction costs and greater uncertainty, which discourages investment. Excessive regulation may decrease benefits from FDI because it hampers reallocation of resources (deters agglomeration effects), 
which can lead to limited spillover effects. Moreover, low quality of institutions may influence the mode of FDI favouring mergers and acquisitions, which has weaker growth effects. Institutional factors, which also restrict employment regulations, can be an important factor of labour mobility as a medium of knowledge transmission.

Local innovation systems and clusters may attract FDI and create an environment for fruitful cooperation between foreign and local firms. An important role in knowledge transfer can be played by the local environment. The ability to build local networks for knowledge transfer through clusters, innovation systems and cooperation with foreign investors constitutes a condition for profits from the FDI presence. Girma et al. (2015) point out that benefits from learning-by-doing and imitation effects can be greater when local firms have a close relationship with transnational companies and adequate resources to absorb knowledge. Regional development theories indicate that spillover effects can be triggered by local innovation systems or clusters based on concentration and cooperation among firms, local authorities and R\&D centres (Yehoue, 2009).

Financial market development may influence the ability to gain profits from FDI. Research confirms that countries with more developed and better regulated financial markets can gain more from FDI and achieve higher economic growth rates (Alfaro et al., 2004). Better access to financing can be important for incoming foreign investors as a complementary source of funding. On the other hand, sophisticated financial markets may spur local entrepreneurship, finance investment, allow for hiring new managers and skilled labour as well as encourage transfer of technology from foreign investors. It means that the financial market development may also influence the capacity for knowledge spillovers from the FDI presence.

Fagerberg et al. (2010) provide a much longer list of complex factors decisive for absorptive capacity such as social conditions (trust and tolerance), quality of governance (corruption, law and order), production quality (international standards, lean production, just in time), openness to trade and ability to innovate.

\section{Investment Development Path}

Economic literature related to factors affecting economic growth is mainly concentrated on a country's attractiveness for FDI inflows (Gammeltoft and Kokko, 2013). Meanwhile, the long-term competitive position of a given country as well its ability to gain proper position in the global labour and value division are also determined by the ability to:

- attract FDI of "good quality" (in terms of sectoral and financing structure),

- internalize knowledge from the FDI presence, which can be a result of the quality of FDI as well as the quality of local resources,

- internationalization of its activity through outward FDI.

The traditional Investment Development Path assumes direct relations between the GDP per capita development and the net FDI position. The concept which combines the evolution of a country's FDI position in terms of inward Foreign Direct Investment (IFDI) and outward Foreign Direct Investment (OFDI) and its level of development is the Investment Development Path (IDP). According to this approach, there is a longterm relation between the level of development and the country's net investment position (NIP) defined as a difference between its outward and inward direct investment stock. The evolution of the country's position, accompanied by increasing GDP per capita, is a result of firms' ability to accumulate assets and engage in outward direct investment.

In practice, internationalization processes through OFDI are demanding in terms of resources and experience. From the new trade theory point of view, firms are heterogeneous in terms of productivity and only "the happy few" of them can use FDI as an internationalization strategy (Mayer and Ottaviano, 2007). Such an approach indicates that the ability to make OFDI can be seen as a competitive advantage which firms use to expand their activity.

Dunning launched the concept of IDP in the 1980s, expressing the role of the interaction between inward and outward FDI and its links with the economic development of a country (Dunning, 1993; see also Daszkiewicz and Wach, 2013). It is divided into four stages - see Figure 1 . 
Figure 1. Investment Development Path

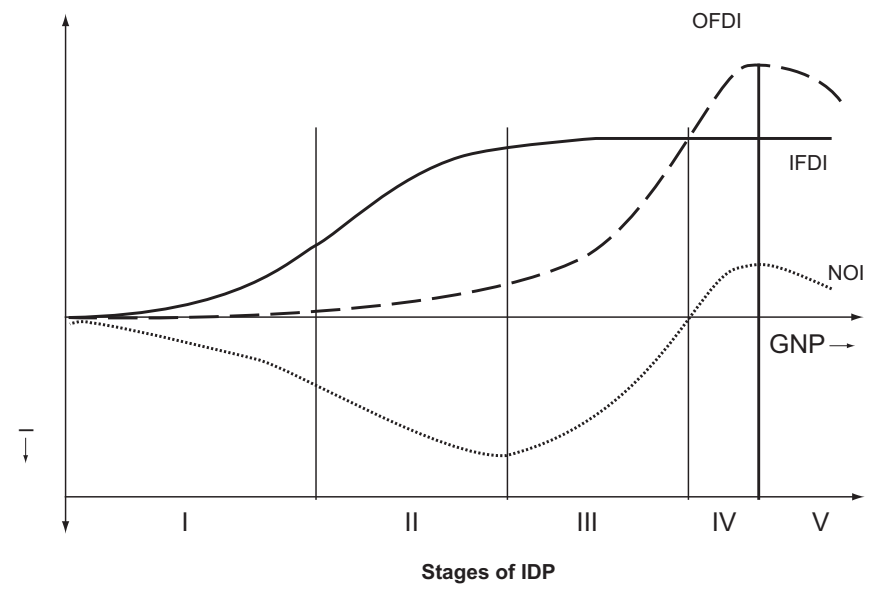

Source: Narula and Guimón (2010).

In stage one, which relates mainly to the least developed countries, FDI inflows, and especially outflows, are minor or even nonexistent because of the lack of competitive advantage of a country and many economic and institutional weaknesses.

In stage two, FDI inflows increase as a result of improving location advantages and growing attractiveness of resources (resource-seeking FDI) and low- and medium-tech industries. Due to the FDI inflow, NIP usually worsens. During this phase, knowledge transfer from incoming FDI is possible, leading to upgrading ownership advantages of local companies and stimulating FDI outflows.

Stage three can be called intermediate because the NIP position is usually also negative but FDI outflows can be higher than inflows because of growing competitiveness of local companies. This intermediate stage shows an increase in the economy's income per capita, an acceleration of industrialization and a bigger specialization of demand oriented towards superior quality products. Competition in the domestic market rises as the ownership advantages of inward investors diffuse through the local industry. As a result, domestic firms start developing their own advantages.

In stage four, the net FDI position turns positive as the FDI outflow surpasses the FDI inflow, with a growing quality of both of them. In stage five, which is characteristic of the most developed countries, the net FDI position, although fluctuating, is close to zero.

\section{Foreign Direct Investment in the Visegrad Countries}

The Visegrad countries have become a very popular destination of FDI usually from the EU neighbourhood countries since the mid 1990s - see Figure 2. This "strategic" inflow was fuelled by many different factors including a close geographical distance, low labour costs and prices and an increasing quality of labour forces, a huge market growth potential and expected EU membership (Schäffler et al., 2015). Initial and spurring factors were also privatization processes accompanied by trade and economic liberalization. FDI influenced the economic and trade structure of the Visegrad countries, increasing the role of industry, importance of intra-industry trade, level of export diversification and also had positive impact on domestic companies' profitability (Rutkowski, 2006).

Attractiveness of the whole CEE region is confirmed by the fact that about two thirds of the total capital inflow before 2006 was in the form of FDI. From the point of view of enterprises, the main motivation for the EU multinational companies was related to efficiency-seeking and marketseeking motives. As documented in Kolasa and Bijsterbosch (2010) and Damijan et al. (2013), FDI presence was an important channel of improving productivity, real 


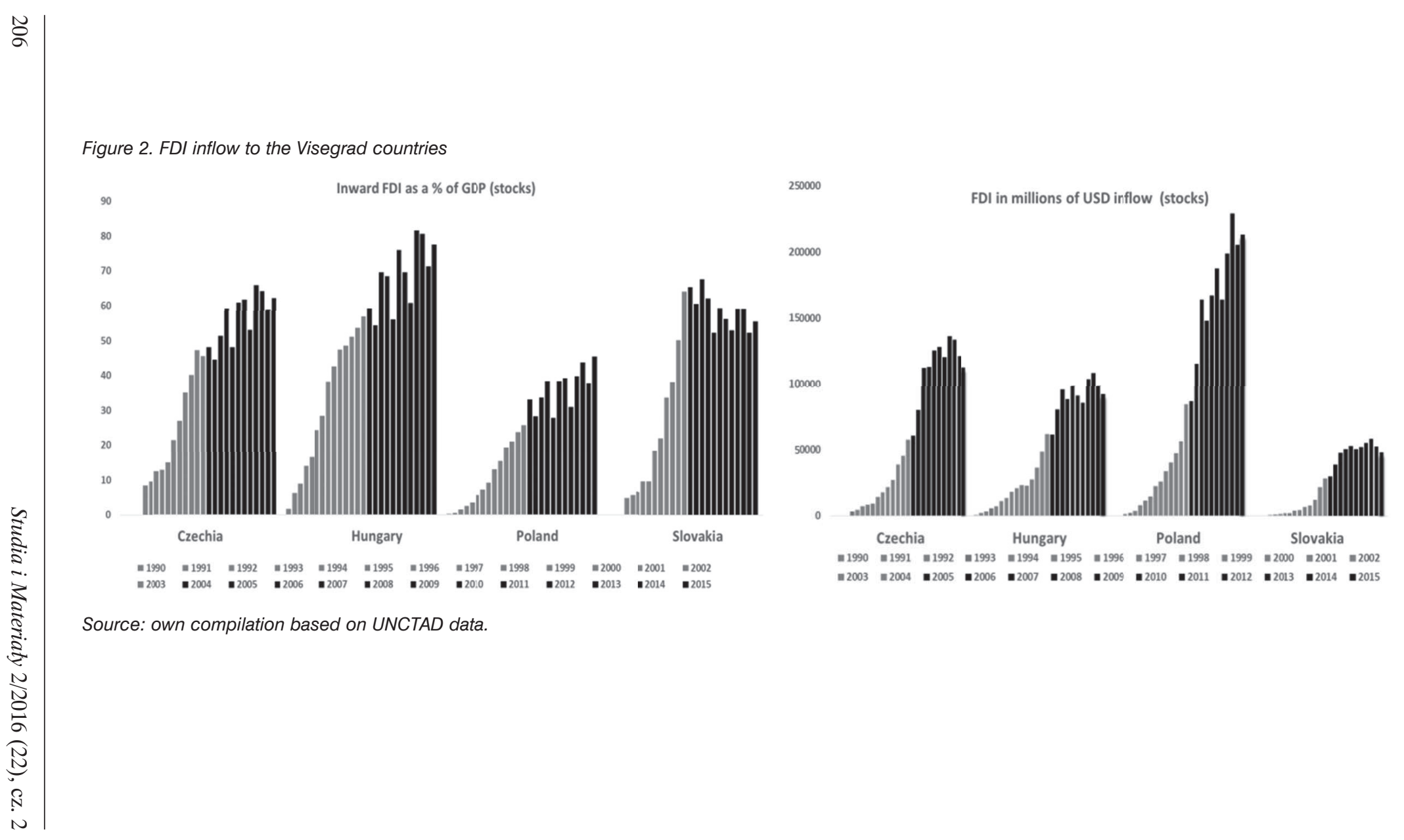


GDP growth and convergence. FDI was also an important channel of the inclusion of the Visegrad countries into Global Value Chains (GVC) through trade, increasing its diversification and sophistication (Tchorek and Czaja, 2015).

In relative terms (measured as a $\%$ of GDP), Hungary was the leading country as a recipient of FDI, followed by Czechia and Slovakia. Due to its size, Poland received lower FDI as a fraction of its GDP. Nevertheless, Poland was the leading country (also thanks to its size) in attracting FDI in absolute terms. Attractiveness of the Polish economy has been increased successfully since the beginning of the 1990s, when the share of FDI directed to Poland constituted about $20 \%$ of the total inflow to the Visegrad group. In the years 20132015 , it was more than $40 \%$ of total FDI inflow.

For all analysed countries, some threshold in FDI inflow coincides with joining the EU. As a subcontractor to the "bazaar economy" (Germany) and other important EU economies (France, Italy, the Netherlands), the Visegrad countries host FDI which was directed mainly to the industry, improving its competitiveness, while invest- ment in the financial sector and other services also usually played a positive role.

Boudier-Bensebaa (2008) indicates (based on data till 2006) that the net FDI position places Czechia, Hungary, Poland and Slovakia in stage one or two of the IDP, while the EU-15 countries can be categorized within stages four and five. Gorynia, Nowak and Wolniak (2010), who analysed the IDP for six CEE countries (the Visegrad countries plus Bulgaria and Romania), classified V4 as stage two, while two latter as stage one. They also mentioned the special case of Poland, which, despite being the least developed among V4, appeared to be closest to the point of transition to stage three. Klich (2014), based on the net FDI position data ending in 2012, noticed that Poland, the Czechia and Slovakia advanced to stage three, while Hungary gained its position a little earlier - see figure 3 .

Observing the Net FDI position among the analysed countries in the Figure 2, it seems that because of its improvement (the difference between outward and inward is decreasing) Czechia, Hungary and Slovakia moved to the stage three of IDP ${ }^{2}$. This observation might be somewhat misleading because during the recent years the Net

Figure 3. Inward and outward stocks and net position of FDI in millions of USD

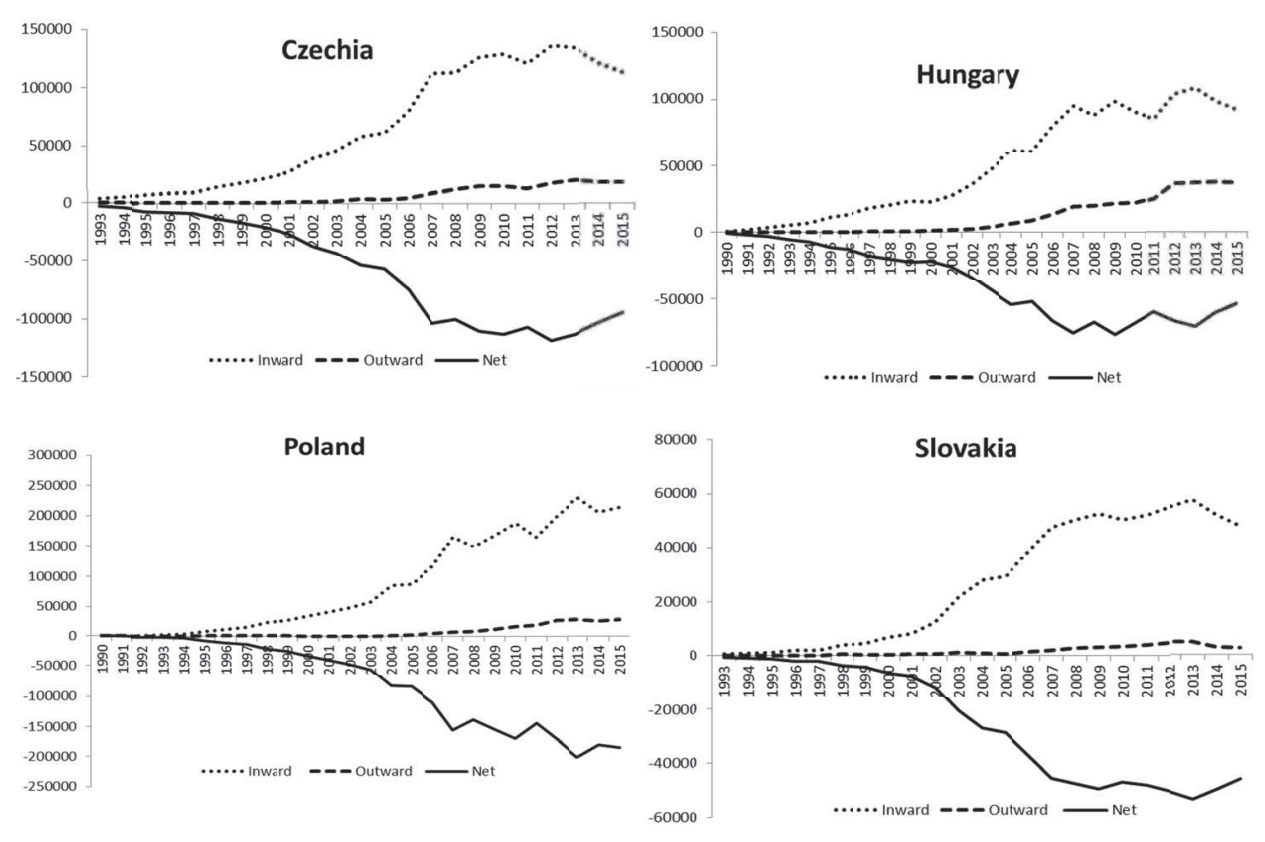

Source: own compilation based on UNCTAD data.

Wydział Zarządzania UW ～DOI 10.7172/1733-9758.2016.22.16 
position improves mainly due to an FDI inflow decrease rather than an OFDI outflow. OFDI has risen in all countries after joining the EU and in recent years (except Slovakia) but its magnitude is still small in comparison to more advanced economies and too small to influence general competitiveness of the country.

\section{OFDI in the Visegrad countries}

Contrary to the IDP assumption, high attractiveness for FDI inflows does not always mean good prospects for OFDI. Slovakia experienced a lot of incoming FDI measured as a share of GDP and GDP per capita, much more than Poland, but it failed to benefit from the FDI presence to build home-based capacity and competitiveness among local companies. To some extent, it is a result of an insufficient number of small and medium-sized enterprises, only a few national companies able to export capital and the fact that state institutions gave more priority to promoting export rather than OFDI. This can confirm that the direct relationship between IFDI and OFDI assumed in the IDP theory may not always exists. The key issue can be the ability to absorb knowledge embodied in FDI and create own capabilities to compete internationally through big local companies.

The ability to export FDI from a given country can have at least two sources. The first one is foreign capital which uses a country's advantages as a base to expand its activity. It means that inward FDI is a source of outward FDI, which is motivated by the MNC strategy and decisions (through GVC or regulatory arbitrage) and generate "capital-in-transit" flows. Benefits from such FDI presence can appear through spillover effects (illustrated in the Figure 4) but they can be minor, because the main motivation for inward and outward FDI may not support direct interconnections between foreign and local companies.

The second source of FDI export, which works rather in the medium and long term, is based on local resources and companies' ability to expand their activity abroad. This process is more profitable for the host economy and companies but is also conditional and depends on absorptive capacity of the local economy. The ability to export FDI should be preceded by the transfer of knowledge from incoming FDI, spillover effect existence and acquisition of important competences by companies - see Figure 5.

The ability to expand activity through FDI can be a measure of international competitiveness of local companies. Internationalization can be a synonym of local firms' stage of development where they expand their activities gradually - see Figure 6. Initially, firms start with export, then are ready for international cooperation (e.g. offshoring) and, as a final stage, they are able to establish their own entities abroad. The phase of companies' development influences the country's competitiveness and the level of income. In order to allow firms to develop, they should be

Figure 4. "Indirect" Direct Investment

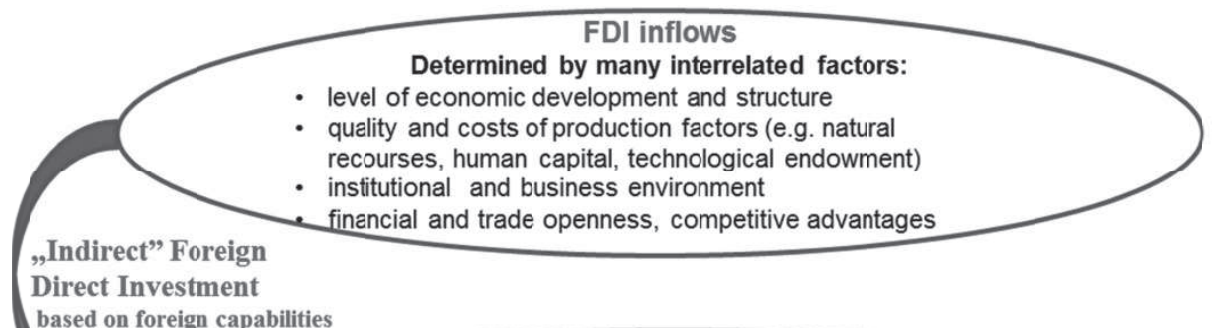

based on foreign capabilities

FDI outflows

- motivated at Multinational Corporation level

- international relations (GVC, networks),

- capital "in transit” flows 


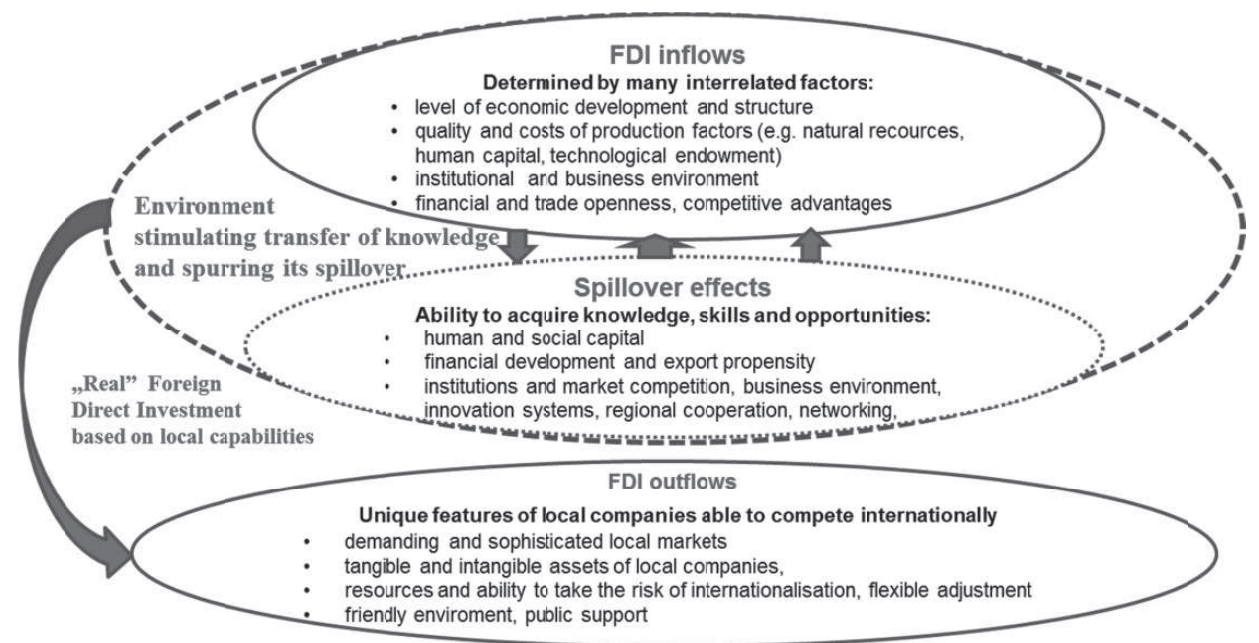

Source: own compilation.

stimulated to grow and expand their activity abroad because this spurs their competitiveness, gives access to new markets, resources and networks. Growing GDP per capita enforces more attention which should be paid to OFDI as an indicator of global competitiveness.

Figure 6. Stages of internationalization

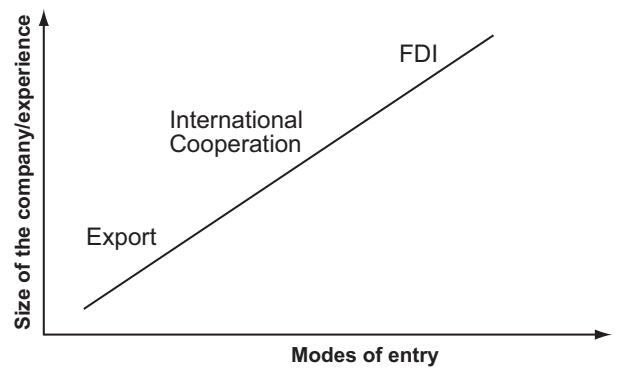

Source: own compilation based on Johanson and Vahle (1990).

Although Polish OFDI is very limited in international comparisons, Polish companies are important foreign investors among CEECs. Poland is the largest OFDI investor among the analysed countries in absolute terms, but OFDI as a $6 \%$ share of GDP ranks it behind Hungary (30\%) and Czechia $(10 \%)$ - see figure 7 . This is a result of the country size, openness to IFDI as well as the transformation path on which Hungary was the first country experiencing a huge FDI capital inflow and a subsequent outflow. The smallest FDI outflow can be seen in the case of Slovakia.

An important source of OFDI is foreign-owned capital. The good position of Hungary (and to some extent the Czechia and Poland) is also an outcome of the phenomenon called "indirect" outward direct investment because the main source of their investment are foreign-owned companies. The problem with evaluating OFDI properly in the analysed countries is the fact that a growing share of OFDI from Hungary, the Czechia and Poland constitutes "capital in transit". This is a result of tax optimization and favourable legal framework seeking foreign-owned and national companies, which is confirmed by an important role of such recipients of the FDI capital as Cyprus, the Netherlands, Luxembourg, Switzerland.

The main motives for OFDI from CEECs are related to market-seeking incentives. CEE countries are still at the early stage of internationalization motivated by market size and growth as well geographical distance. This is confirmed by a cross- country analysis of the analyzed CEECs based on Amadeus data (Cantner et al., 2013; Hassan et al., 2015). Kowalewski and Radło (2013) examined motives for Polish OFDI at the company level and confirmed that these are mar- 
Figure 7. Outward FDI in the Visegrad countries as a \% of GDP

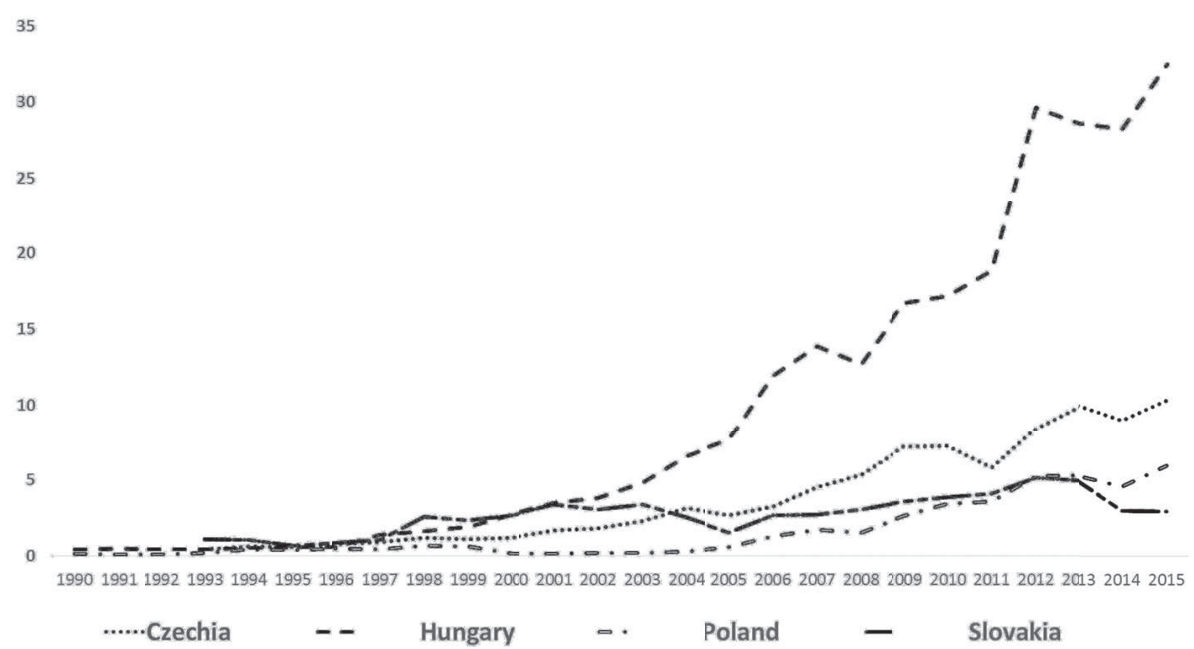

Source: own compilation based on UNCTAD data.

ket-seeking and resource-seeking motives, which is characteristic for the earlier stages of internationalization. Gorynia et al. (2013) conducted an analysis based on ten deeply explored OFDI case studies of Polish firms and noticed that their motives are in line with Dunning's assumption and are mainly driven by market-seeking motives and that the prevailing mode was acquisition. What is surprising, strategic assets and efficiency-seeking motives, which are typical for mature multinational companies, also played an important role. The key obstacle for expansion was the lack of funds, managerial skills and previous experience on Polish and foreign markets. An inadequate innovativeness level was indicated rarely.

CEECs follow a gradual internationalization model. Geographical proximity and market-seeking motives can be explained be the theory called the "Uppsala model". According to it, the internationalization process is sequential and depends on companies' age, size and experience, which is positively correlated with the ability to go abroad, starting with indirect export, turning to direct export, outsourcing and FDI. It also means that companies starting their international activity in the nearest neighbourhood spread with accumulated knowledge and resources. This is in line with the new trade theory assumptions.
Companies from CEECs also seek better regulation abroad. Hassan et al. (2015) conducted interesting research examining the role of host countries' economic institutional factors which affect an OFDI decision by companies from the CEE countries which joined the EU in 2004 and 2007. Based on the firm-level data on 951 greenfield investment projects from 1995 to 2010, they confirmed that firms from 10 CEE countries prefer destinations with better institutional environments than those in their home countries. The analysis confirms the significance of the following factors as triggers of investment location: high property rights protection, freedom from corruption, low bureaucratic burdens, high financial freedom, which means better access to finance, monetary freedom used as a proxy of macroeconomic stability and a low tax burden.

The old EU countries remain a source of legal and institutional quality. The effects of those factors are stronger in the case of OFDI flows to EU-15 than to other CEE countries. On the one hand, this can reflect the insufficient level of economic institutional development in the CEE countries, and transaction cost and investment uncertainty reduction seeking motives, on the other. The authors also confirmed the role of traditional location factors such as market growth and geographical distance. 


\section{Conclusions}

FDI may constitute an important factor for increasing income convergence between rich and poor countries. Nonetheless, the ability to gain profits from FDI presence depends on many circumstances related mainly to the quality of production factors of the host country. This is also demanding for policy makers who should try to shape the FDI structure.

Incoming FDI and the ability to learn from its presence as well as increased quality of local resources and capabilities to improve export capacity should help to change the FDI position from import FDI to export them. It is a long-term, sequential process which demands fulfilling many conditions. One of them is building financial capital, entrepreneurship and unique resources of local companies. It is feasible to do in cooperation and coexistence with foreign investors, which should spur spillover effects.

According to the investment development path hypothesis, GNP per capita depends not only on FDI inflows, but primarily on the ability to generate own FDI abroad. Achieving high absorptive capacity level allows for benefitting from the presence of FDI and building competitiveness and innovation of national entities. They need to search for markets, resources and technology outside their own country due to the fact that the potential to benefit from the inflow of FDI is subject to certain restrictions. The presence of domestic companies in foreign markets is an important condition for the development of and access to knowledge and innovation internationally.

Based on the literature review and raw data, we can claim that the Visegrad countries generally used the opportunity arising from the FDI presence and now they are moving to stage three of Investment Development Path. It confirms their increasing international competitiveness. Inward and outward FDI position differs slightly between analysed countries but the EU integration unified the investment path. Due to specific features related to the size of the country and enterprises and the structure of FDI inflow, Slovakia seems to be a laggard in terms of the ability of internationalization in the form of FDI.

\section{Footnotes}

1 Cantner et al. (2013) indicate the important role of the skilled labour force availability as a factor determining OFDI decisions.

2 Examining Investment Development Path for Poland, Ciesielska (2014) and Kłysik-Uryszek (2013) indicate that the Polish economy is moving from stage two to stage three. It is a result of a much more intensive pace of outward FDI than FDI inflow, especially after 2004 and during the financial crisis.

\section{References}

Alfaro L., Chanda A. and Kameli-Ozkan Sayek, S. (2004). FDI and economic growth: the role of local financial markets. Journal of International Economics, 64, 113-34.

Ali, F., Fiess, N. and MacDonald, R. (2010). Do institutions matter for foreign direct investment? Open Economies Review, 21(2), 201-219.

Bijsterbosch, M. and Kolasa, M. (2010). FDI and productivity convergence in Central and Eastern Europe: an industry level investigation. Review World Economy, 145(4), 689-712.

Bluedorn, J., Duttagupta, R., Guajardo, J. and Topalova, P. (2013). Capital Flows are Fickle: Anytime, Anywhere. IMF Working Paper No 183.

Borensztein, E., De Gregorio, J. and Lee, J.W. (1998). How does foreign direct investment affect economic growth? Journal of International Economics, 45(1), 115-135.

Boudier-Bensebaa, F.(2008). FDI-assisted development in the light of the investment development path paradigm: evidence from Central and Eastern European countries. Transnational Corporations, 17(1), 37-63.

Broto, C., Diaz-Cassou, J., Erce, A. (2011). Measuring and explaining the volatility of capital flows to emerging countries. Journal of Banking and Finance, 35(8), 1941-1953.

Bruno, R and Campos, N. (2013). Reexamining the conditional effect of foreign direct investment. IZA Discussion Paper (7458).

Cantner, U., Günther, J. Hassan, S.S. and Jindra, B. (2013). Outward FDI from Central and East European Transition Economies-A discrete choice analysis of location within the EU. Munich Personal RePEc Archive, No 18, January.

Ciesielska, D. (2014). Czynniki kapitałowej ekspansji międzynarodowej polskich przedsiebiorstw. Zeszyty Naukowe Uniwersytetu Szczecińskiego. Finanse. Rynki finansowe. Ubezpieczenia, 603-612.

Damjan, J., Kostevc, Č. and Rojec, M. (2013). FDI, structural change and productivity growth: global supply chains at work in Central and Eastern European countries. IRMO Occasional Papers, 2013(1), 2-29. 
Daszkiewicz N., and Wach K. (2013). Mate i średnie przedsiębiorstwa na rynkach międzynarodowych, Wydawnictwo Uniwersytetu Ekonomicznego, Kraków.

Dunning, J. (1993). Multinational Enterprises and the Global Economy. Wokingham: Addison-Wesley.

Dunning, J. and Lundan, S. (2008). Multinational Enterprises and the Global Economy. Second Edition. Cheltenham, UK: Edward Elgar.

Fagerberg, J., Srholec, M. and Verspagen, B. (2010). Innovation and Economic Development in: Hall B, and Rosenberg N. (Eds.), Handbook of the Economics of Innovation. Vol. II. North Holland, s. 833-872.

Gammeltoft, P. and Kokko, A. (2013). Introduction Outward foreign direct investment from emerging economies and national development strategies: three regimes. International Journal of Technological Learning, Innovation and Development, 6(1/2), 1-20.

Girma, S., Gong, Y., Görg, H. and Lancheros, S. (2015). Estimating direct and indirect effects of foreign direct investment on firm productivity in the presence of interactions between firms. Journal of International Economics, 95(1), 157-169.

Gorodnichenko, Y., Svejnar, J. and Terrell, K (2014). When does FDI have positive spillovers? Evidence from 17 transition market economies. Journal of Comparative Economics, 42(4), 954-969.

Gorynia, M., Nowak, J. and Wolniak, R. (2010). Foreign Direct Investment in Central and Eastern Europe: The IDP trajectories of selected countries. Poznań University of Economics Review, 10(1), 5-26.

Gorynia, M., Nowak, J., Trapczyński, P. and Wolniak, R. (2013). Internationalization of Polish Firms via Foreign Direct Investment: A Multiple-Case Study Approach. In: M.A. Marinov and S.T. Marinova (eds), Successes and Challenges of Emerging Economy Multinationals. Palgrave Macmillan.

Hagemejer, J. (2015). Productivity spillovers in the GVC. The case of Poland and the New EU Member States.

Hanousek, J., Kocenda, E. and Maurel, M. (2011) Direct and indirect effects of FDI in emerging European markets: A survey and meta-analysis. Economic Systems, 35, 301-322.

Hassan, S.S. (2015). Economic Institutions and the Outward FDI Location Strategies of Emerging Market Multinational Business Groups: Evidence from Central and Eastern European Countries. Review of Economics and Institutions, 6(1),
Johanson, J., Vahlne, J.-E. (1990). The Mechanism of Internationalisation. International Marketing Review, 7(4).

Jude, C. and Levieuge, G. (2015). Growth effect of FDI in developing Countries: the role of institutional quality. Banque de France, Document De Travail, No 559, June.

Kinoshita, Y. (2011). Sectoral Composition of Foreign Direct Investment and External Vulnerability in Eastern Europe. IMF Working Paper.

Klich, J. (2014). Foreign Direct Investment in the The Visegrad Countries after 2004: Have the The Visegrad Countries`Membership in the European Union Changed Something? Entrepreneurial Business and Economic Review, 2(3), 19-31.

Kłysik-Uryszek, A. (2013).Ścieżka rozwoju inwestycji (koncepcja IDP). Doświadczenia Polski. Przeglad Zachodniopomorski 3/2, 187-200.

Kowalewski, O. and Radło, M.-J. (2013). Motywy inwestycji zagranicznych polskich przedsiebiorstw. Acta Universitatis Nicolai Copernici, Ekonomia, XLIV, 2, 177-192.

Mayer, P. and Ottaviano G.I.P. (2007). The happy few: the internationalization of European firms. Blueprint 3, Bruegel.

Mitra, P. (2011). Capital Flows to EU New Member States: Does Sector Destination Matter? IMF, WP, 2011.

Narula, R. and Guimón, J. (2010). The investment development path in a globalized world: implications for Eastern Europe. Eastern Journal of European Studies, 1(2), 5-19.

Yehoue, D.B. (2009). Clusters as a driver for FDI. Economic Modelling, 26, 934-945.

Rutkowski A. (2006). Inward FDI, Concentration, and profitability in the CEECs: Were the domestic firms crowded out or strengthened?, Transnational Corporations. United Nations Publishing, 15(3), 105-139.

Schäffler, J., Hecht V., and Michael M. (2015). Regional Determinants of German FDI in the Czech Republic - Evidence from a gravity model approach, Beiträge zur Jahrestagung des Vereins für Socialpolitik Ökonomische Entwicklung - Theorie und Politik - Session: Foreign Direct Investment I, No. D05-V2.

Tchorek G., and Czaja J. (2015). Accession to the European Union as a Driver for Polish Trade, red. Adamczyk A., Dubel P., The European Union and Poland. Problems and Achievements, Wydawnictwo Poltext, 125-150. 